\title{
The politics of diversity: Social and political integration of immigrants in Iceland
}

\author{
Porgerður Einarsdóttir, Professor, University of Iceland \\ Thamar M. Heijstra, Assistant Professor, University of Iceland \\ Guðbjörg Linda Rafnsdóttir, Professor, University of Iceland
}

\begin{abstract}
The ethnic diversity of modern states raises the question of where successful countries are in terms of immigrant inclusion. The number of immigrants in Iceland has increased significantly since 2004, and by the end of 2016, immigrants made up around $10 \%$ of the population of Iceland. Research reveals a gap between immigrants and natives in terms of social and political inclusion. This paper examines the social and political integration of male and female immigrants in Iceland via comparisons with the native population. We ask how native Icelanders and people with a non-Icelandic background experience their social position and political participation within Icelandic society. We focus on political efficacy, ideas about what makes a good citizen, and subjective status position as indicators of the degree of social and political integration. We use data from the 2014 International Social Survey Programme (ISSP) on Citizenship, which is based on a random sample of 2,000 individuals and random samples of 600 individuals each targeting two of the largest immigrant groups in Iceland-Lithuanians and Poles_-as well as the largest Asian immigrant group: Filipinos. Although the findings show integration of immigrants up to a certain extent, the differences between Icelandic and non-Icelandic participants are apparent and include certain disadvantages for participants with a foreign background. Although other variables—such
\end{abstract}


as income, education, paid employment status, and age-play a larger role in social and political status than foreign nationality, the findings of this study suggest that there is room to improve the integration of immigrants in Iceland.

Keywords: Citizenship; diversity; integration; immigrants; participation.

\section{Introduction}

Iceland, like many other countries, relies heavily on an immigrant workforce. However, immigrants have long been seen as a temporary workforce in Iceland, representing numbers so small that they could be neglected in official policy making. Hence, Iceland has been lagging behind in the theoretical and practical debates surrounding the civic integration of immigrants, which has long been a priority in Western Europe (Joppke 2017) and in the Nordic countries (Borevi et al. 2017; Simonsen 2017). Only in the last decade, with the rise of the immigrant population in Iceland, have there been policies in place concerning the integration of immigrants into Icelandic society (Félagsmálaráðuneytið 2007). These policies became necessary as the number of immigrants in Iceland increased significantly, from $1.4 \%$ of the population in 1980 to $8 \%$ in 2016 (Statistics Iceland 2017). Although immigration to Iceland is still predominantly work-related, it is now considered to be more often permanent than temporary. This became apparent during the financial crisis of 2008, when the majority of foreign workers decided to stay in Iceland rather than return to their home countries, even if they had lost their jobs (Garðarsdóttir \& Bjarnason 2010). The swift and steep increase in foreign labor is testing Iceland's ability to secure social and political integration.

The fast-growing research field on immigrants in Iceland has so far mainly addressed labor market issues and the situation of immigrants in Iceland, such as their communication and negotiation position (Christiansen \& Kristjánsdóttir 2016), their well-being and living conditions (Barille \& Meckl 2016; Ólafsson \& Meckl 2013; Skaptadóttir 2015a; Skaptadóttir 2010b), their experiences with employment (Christiansen \& Kristjánsdóttir 2016; Loftsdóttir, Sigurðardóttir \& Kristinsson 2016; Skaptadóttir 2015b) and unemployment (Einarsdóttir 2011; Wojtynska 2011), and the attitudes of Icelanders towards immigrants in general (Loftsdóttir 2015a; Loftsdóttir 2015b; Önnudóttir 2009). However, the social_ and in particular, the political — integration of male and female immigrants in Iceland remains an under-researched area. In this paper, we aimed to take some steps toward filling this gap in the literature. A point of departure for our approach is Marshall's (1950) prevailing concept of social citizenship in terms of equal civil, political, and social rights, which are considered to be universal and accorded to all members of society. We explore the Icelandic context against historical and ongoing concerns that the assumed rights, belonging, and participation of all are not translated into full integration of marginalized groups (Young 1989). We use data from the 2014 International Social Survey Programme (ISSP) and ask how native Icelanders and people with a nonIcelandic background_-specifically Poles, Lithuanians, and Filipinos-experience their 
social and political integration and how they connect this integration to their subjective (self-reported) position within Icelandic society. We focus on political efficacy, which is an indicator of the degree of political integration. The text is structured as follows: We begin with a presentation of our theoretical perspectives, followed by an introduction of the Icelandic context for immigrant issues. We then present our data, research questions, and results, and we end with a discussion and concluding remarks.

\section{Theoretical perspectives}

In most Western European countries, civic integration policies have been in place since the 1990s, replacing the previously laissez-faire approach, in which immigration was "left to the free play of society's institutions," such as the labor market (Joppke 2017, 1153). In Marshall's (1950) historical account of citizenship, civil citizenship consists of the rights that are necessary for individual freedom and liberty, social citizenship entails economic welfare and security, and political citizenship is "the right to participate in the exercise of political power" (Marshall 1950, 11). But what is the most feasible way to conceptualize integration today? Currently, different concepts are employed by scholars, such as "assimilation, incorporation, integration and acculturation" (Morales \& Giugni 2011, 1). Generally, assimilation is conceived as an uncritical adaptation of immigrants into the mainstream culture (Einarsdóttir \& Gústafsdóttir 2008). However, as Morales points out, although assimilation has negative ideological connotations in relation to "mainstream cultural and political values," it has positive connotations when immigrants share the socio-economic positions and status of the majority population (Morales 2011, 21). According to Morales, there does not seem to be any obvious or substantial difference between "integration" and "incorporation," so we will use "integration" in order to bring clarity to our discussion.

The political element of citizenship is vital in contemporary democracies. Negative views towards the political system are considered to lead to alienation, which erodes the legitimacy of the democratic system (Almond \& Verba 1963). Therefore, the political marginalization of marginalized groups, such as immigrants, not only maintains the groups' position as outsiders but also negatively affects democratic representation and accountability. It is "likely to spill over to their social and economic integration, as the policy process will fail to address adequately their need in these domains" (Morales \& Giugni 2011, 1). These issues are always important, but in times of declining political trust and increased immigration, the political integration of immigrants is of even greater significance. This also raises questions about the social and economic situation of immigrants, not least whether they consider themselves to be active agents in the political system and to what extent they think that the political system is receptive to their needs and demands (Anduiza \& Josep 2011). Research on the political participation of immigrants in terms of voting suggests that higher levels of education and income increase the likelihood and motivation of immigrants to participate in elections (Chaudary 2017; Bevelander \& Pendakur 2010). This also applies to Iceland (Skaptadóttir 2012).

Political efficacy is another important part of political integration; it is the individu- 
al's sense of competence in influencing the political system and the ability to impact the political process (Campbell et al. 1954, cited in Anduiza \& Josep 2011, 199). In the same manner, political alienation is the lack of sense of political efficacy in general (Konttinen \& Kouvo 2009). In some cases, a distinction is made between internal and external efficacy, in which internal efficacy is the individual's perception of their own ability to impact the political process, and external efficacy is the perception that the political system is responsive to the individual's demands. However, we do not distinguish between these types of efficacy because they are closely related and to some extent include elements of each other (Konttinen \& Kouvo 2009, 38). In general, the more resources citizens have, the more likely they are to have high levels of political efficacy, and the sense of political alienation tends to be strongest among those with the least amount of resources (Konttinen 2009).

Another theoretical approach we utilize revolves around what makes a good citizen. The modern ideas of being a good citizen — consisting of social and legal rights, as well as duties_ — can be traced to Marshall's theory of citizenship (1950). Blom (2009, 132133) identifies three blocks of ideas defining a good citizen. The first block includes dimensions that link together political and moral elements, addressing issues such as the importance of voting, obeying laws, and not evading taxes. The second block includes duties such as helping people who are worse off than oneself and keeping watch on the actions of the government. The third block, and of least importance to the notion of a good citizen, includes political, ethical, and environmental reasons for choosing consumer products. In this paper, we examine the ideas of immigrants in Iceland concerning a good citizen in comparison to those of native Icelanders.

To further contextualize the social position of immigrants and the native population in Iceland, we explored the issue of subjective social status. The subjective social status approach aims to complement the approach focused on objective social status, or class position, which entails access to resources like education, income, and social influence. The MacArthur Scale of Subjective Social Status (Adler \& Stewart 2007) is commonly used in this respect; it uses a symbolic ladder in which people place themselves on a particular rung within a vertical social ladder. By employing this scale, Gidron and Hall (2017) found that subjective social status is an indicator of social integration. They established connections between social disintegration and political alienation: The lower a person's subjective social status, the larger the likelihood of political alienation. They also found that those who feel socially marginalized are more likely to be alienated from society's political system (2017). Traditionally, Icelanders have adhered to egalitarian values, and they have long believed Iceland to be a classless society, although this has been contradicted by empirical evidence. Furthermore, Icelanders tend to have more of a "middle class" view of their subjective class position, and they view it as higher than that of people in most other countries (Oddsson 2010). An important question in this respect is whether this applies to immigrants and native Icelanders alike.

Against this theoretical and conceptual background, this study examined the situation of male and female immigrants within the Icelandic labor market, their social 
position and political integration within Icelandic society. The research questions that we put forward are the following: How are people with a non-Icelandic background experiencing their participation and position within Icelandic society and their political integration? Do they experience their situation differently than people with an Icelandic background? Do people with a non-Icelandic background value being good citizens to a different extent than Icelanders? Where do they place themselves on the societal ranking scale in comparison to Icelanders? We further ask whether there is a difference in this respect among Icelanders, Lithuanians, Poles and Filipinos. In addition, we ask whether there are more differences, if any, between the groups that belong to the EEA countries on the one hand (Icelanders, Lithuanians, Poles) and those who do not (Philippines) on the other hand. This is important to the discussion of social and economic integration, which is the focus of this article.

\section{The Icelandic context}

The Icelandic labor market has traditionally been a flexible one, and it continues to be so. It is also characterized by high participation rates for both men and women and a low unemployment rate. Due to the country's booming economy in the beginning of the 21 st century and its relatively quick recovery after the economic crisis of 2008, there has been a demand for foreign labor in Iceland. Before the 1990s, the level of immigration to Iceland was low; the labor market was homogeneous, and most foreign citizens were from the Nordic countries. After 1990, there was a large influx of immigrants from other European countries, mainly from Poland and Lithuania, and from some Asian countries as well, mainly the Philippines (Júlíusdóttir, Skaptadóttir \& Karlsdóttir 2013; Skaptadóttir 2010b). In 1998, foreign employees made up 3\% of the Icelandic workforce, but this percentage has increased steadily since then, reaching $9.7 \%$ in 2016 . The increase in employment has mostly been linked to the tourism, service, and construction industries, and most of these jobs do not require specialized education (Vinnumálastofnun 2016). Until 2004, women immigrants outnumbered men, but an increase in men's immigration from 2005 can to a large extent be explained by the influx of workers into the construction industry (Júlíusdóttir, Skaptadóttir \& Karlsdóttir 2013). During and after the economic crisis, Icelandic literacy has been made a requirement for these jobs more frequently than it was during pre-crisis times (Innes \& Skaptadóttir 2017). Although Iceland is not a member of the European Union (EU) it has been a member of the European Economic Agreement (EEA) since 1994 (currently 31 states). This agreement provides for the free movement of persons, goods, services, and capital within the European single market, including the freedom to choose residence in any country within this area. The EEA and the EU form a single labor market. In 2000, Iceland also became a part of the Schengen Agreement, a convention implemented in 1995 to abolish internal border controls between member countries (currently 26 states).

A closer examination of the group of immigrants living in Iceland reveals that the largest immigrant group in January 2017 was from Poland, and the second largest group came from Lithuania. These groups belong to the EEA. The largest group outside the 
European Economic Area, besides those from the USA, came from the Philippines. After regulations opened up for free movement and equal labor market rights for people within the EEA, it became more difficult for people from outside the area to get a work permit for Iceland. These changes made it more difficult for immigrants from other areas-Asia, for example_-to get work. It has also made family reunification difficult for this group because it complicates the process of finding work for family members once they are in Iceland (Júlíusdóttir, Skaptadóttir \& Karlsdóttir 2013; Kristjánsdóttir 2010; Skaptadóttir 2010a). In other words, immigrants from Asia and the EEA do not have equal opportunity in terms of their ability to obtain work in Iceland, even though Skaptadóttir (2010b) and Skaptadóttir (2015) show that immigrants from the Philippines generally adapt well to Icelandic society.

Although Iceland has a system of generally applicable collective agreements, meaning that employers outside the agreement in a given industry must comply with the wage and working conditions of nationwide agreements_-foreign workers are believed to be more vulnerable to abuse due to language barriers and/or limited knowledge of the rules and work conditions of the host country. Moreover, they may be willing to accept work conditions that are below Icelandic standards, as long as they are superior to those in their home country.

In general, immigrants in Iceland can apply for Icelandic citizenship (naturalization) if they have resided in Iceland for a period of seven years and fulfilled the conditions of the Icelandic Nationality Act (no 100/1952), which includes residence requirements (Article 8) and special requirements (Article 9). The latter contains a regulation from 2009 stating that applicants must pass a test in Icelandic. It is now believed that language competence enhances integration and that a lack of integration is increasingly given as reason for denying people rights and citizenship (Borevi 2010; Innes \& Skaptadóttir 2017; Joppke 2007). For people outside the European Economic Area (EEA) and the European Free Trade Association (EFTA), Icelandic language skills have also been made mandatory when applying for a residence and work permit in order to get them to demonstrate their willingness to learn and adhere to national norms by attending at least 150 hours of Icelandic classes (Innes \& Skaptadóttir 2017). A study by Innes and Skaptadóttir (2017), predominantly based on interviews with people from Poland and the Philippines, reveals that many immigrants viewed the Icelandic language as the largest hindrance to integration and acceptance. They commonly worked only with other immigrants in a very segregated labor market and received very few opportunities to practice what they learned during the Icelandic classes. We believe that a study like ours will help highlight to what extent the largest European immigrant groups in Iceland (from Poland and Lithuania) and the largest Asian immigrant group (from the Philippines) feel integrated into Icelandic society.

\section{Study description: Data collection and data}

The data for this study were collected in 2013 using the ISSP 2014 Citizenship II questionnaire, which was conducted via a mixed-mode web and postal survey on citizenship. 
A random sample of 2,200 individuals within the adult population in Iceland was taken from the Registers of Iceland, which includes all persons who are or have been domiciled in Iceland and Icelandic citizens residing abroad. In order to receive an Icelandic identity number, one must register here, making it a preferable starting point for any social research that requires a random population sample. Three more random samples of 600 individuals each were collected from the Registers of Iceland, this time targeting Lithuanians, Poles, and Filipinos living in Iceland in particular. This was done in order to guarantee their representation within the study.

An introductory letter containing a URL linked to a web survey on citizenship, a user ID, and a password were sent to sampled individuals, along with information on how to get a paper survey if preferred. A week later, a thank you card was sent to all participants, thanking those who had completed the survey and reminding those who had not of the URL and of how to get a paper questionnaire. On day 22, a follow-up letter was sent, including a paper questionnaire. The survey was made available in four languages; Icelandic, Lithuanian, Polish, and Filipino/English.

A total of 4,000 individuals were invited to participate in the survey, 2,200 from the random sample of the Icelandic adult population and 600 individuals from each of the immigrant target groups: Lithuanians, Poles, and Filipinos. The total response rate was $39 \%$, but the response rates of the target groups with a foreign background were lower: a 14\% response rate for individuals with a Lithuanian background, 11\% for the Polish sample, and $14 \%$ for the Filipino sample. These low response rates are in line with trends visible in other countries, such as Denmark (Deding, Fridberg \& Jakobsen 2008) the Netherlands (Feskens et al. 2007; Feskens et al. 2006; Dale \& Haraldsen 2000), and Finland (Larja \& Kotilainen 2014), where low response rates among immigrant groups have been identified as problematic, and researchers have argued that surveys must be tailored to fit immigrant groups. Although we acknowledge the problem of the low response rate among our participants with a foreign background, which limits the generalization capacity of the research, we nevertheless believe that because the topic is under-researched, it is important to proceed, to get the findings in the open, and to increase discussion on the position of people with a non-Icelandic background in Icelandic society.

Although the Pew Research Center (2012) has argued that despite very low response rates, [surveys that] "are weighted to match the demographic composition of the population continue to provide accurate data on most political, social and economic measures", we have decided against weighting the data in this study; we believe that weighting may actually skew our data further from reality. It is not unthinkable that the non-Icelandic participants in our data are in some ways more privileged that those that refused to participate or those we could not make contact with. Weighting the data would give the impression that we could have dealt with this limitation of the data set, when in fact we are unable to do so. The Pew Research Center also refers to telephone surveys rather than to web or paper surveys, but we are certain that the issue of a certain group of people being more likely to participate in surveys applies to both phone and web/ paper surveys. 
In order to have the most representative data possible, we focused the analysis on individuals between the ages of 25 and 50 years; most of the participants with a foreign background were of those ages. This means that the Icelandic sample that we based the analysis on was reduced to 723 individuals between the ages of 25 and 50 years, and the sample of participants with a non-Icelandic background consisted of 177 individuals. We took gender into account in our analysis whenever there was reason to do so and when the data set allowed for it.

\subsection{Variables and analysis}

After the data collection was completed, the data was edited and anonymized according to ISSP standards and delivered to GESIS Data. The core of the survey consisted of questions regarding political and social participation and membership. In this study, we analyzed three dependent variables: political efficacy, being a good citizen, and subjective social status in terms of top/bottom ranking. Political efficacy-in terms of the influence and knowledge that citizens experience in society-was based on four statements, three of which are put forward in a negative way: I have no influence on what the government does; the government doesn't care what people like me think; I have a good understanding of important political issues; and most people are better informed than I am. The participants were asked to respond to these statements using a five-category Likert scale ranging from strongly agreeing (1) to strongly disagreeing (5), with a neutral middle answer.

The second dependent variable, being a good citizen, was composed of a set of nine statements regarding the perceived obligations of citizenship. Prior to these nine statements was the following introductory text (in Icelandic): There are different opinions on what it means to be a good citizen. What is your evaluation of the following items, on a scale from $1-7$, where 1 means not at all important, and 7 means very important? How important is it to: 1) Always vote in elections; 2) Never try to evade taxes; 3) Always obey laws; 4) Keep watch on the actions of government; 5) Be active in social or political associations; 6) Understand other opinions; 7) Choose products for political or environmental reasons; 8) Help less privileged people in Iceland; 9) Help less privileged people in the rest of world. A Cronbach's alpha analysis revealed that the statement "always obey laws" should be removed in order to reach an acceptable level of internal consistency $(\alpha=0.722)$.

The third dependent variable that we examined in this study was top/bottom ranking, previously referred to as the MacArthur Scale of Subjective Social Status (Adler \& Stewart 2007), where citizens place themselves on the social ladder in society. This variable was measured at an interval scale from 1-10, where 1 represents bottom-rung placement and 10 a top-rung placement in society.

The variables above formed the set of dependent variables, and the background variables were as follows: sex (male or female), background (Icelandic or non-Icelandic), country of origin (Iceland, Lithuania, the Philippines, or Poland), and age (measured in years). Other independent variables included work (in terms of paid employment) edu- 
cational level (measured in years), and monthly income (measured in units of 100,000 Icelandic krona [ISK]). A brief demographic analysis revealed that the mean ages for participating men and women were similar. The Icelandic men (39) were on average one year older than the Icelandic women (38), whereas among participants with a nonIcelandic background, both men and women were on average 36.5 years old.

Eighty-seven percent of the Icelandic male participants $(n=274)$ and $78.5 \%$ of the Icelandic female participants $(n=284)$ were engaged in paid work, in comparison to $90 \%$ of the male participants with a non-Icelandic background $(n=44)$ and $85 \%$ of the female participants with a non-Icelandic background $(n=78)$. Icelandic participants had on average 17 years of education, in comparison to 14 years for male participants with a foreign background and 15 years for female participants with a foreign background. In terms of individual income, Icelandic men had the highest mean income at 635,000 ISK (standard deviation (SD): 405,000 ISK), Icelandic women had a mean income of 427,000 ISK (SD: 216,000 ISK) per month, in comparison to 370,000 ISK for men with a foreign background (SD: 135,000) and 327,000 ISK for women with a foreign background (SD: $172,000)$. The data were analyzed using the statistical computer program SPSS, version 24 , and the analyses included descriptive statistics, chi-square tests, independent sample t-tests, and a linear regression analysis. The level of significance was set at 0.05.

\section{Findings}

\subsection{Political efficacy}

In order to shed light on political efficacy, we first examined the relationship of citizens with the government. When asked how much influence participants felt they have, 40\% of the participants with a non-Icelandic background agreed that they have no influence on what the government does. Table 1 displays the answers in more detail, according to the various respondent backgrounds. We see that the answers of the Lithuanian and Polish participants bear the most resemblances to each other, whereas the Filipino participants tended to have a more optimistic view on the matter, a view that is closer to the Icelandic answers. More Icelanders (23\%) than Filipinos (19\%) agreed with the statement that they have no influence on what the government does; however, a larger group of Filipinos (30\% of Filipinos versus 14\% of Icelanders) had a neutral view on that. Gender did not have a significant effect on whether participants agreed or disagreed with the statement.

Table 1. I have no influence on what the government does

\begin{tabular}{lcccc}
\hline & Icelandic background & Lithuanian background & Polish background & Filipino background \\
\hline Agree & $23 \%(165)$ & $58 \%(35)$ & $50 \%(21)$ & $19 \%(10)$ \\
Neutral & $14 \%(101)$ & $22 \%(13)$ & $21 \%(9)$ & $30 \%(16)$ \\
Disagree & $63 \%(445)$ & $20 \%(12)$ & $29 \%(12)$ & $51 \%(27)$ \\
Total & $100 \%(711)$ & $100 \%(53)$ & $100 \%(42)$ & $100 \%(53)$ \\
\hline
\end{tabular}

$\chi^{2}:(6, \mathrm{n}=866)=70.044, \mathrm{p}=0.000$ 
Table 2 shows that when enquiring about another situation-whether participants feel that the government cares about what citizens (people like me) think- $52 \%$ of the participants with a foreign background were of the opinion that the government does not care about what citizens think, in comparison to $47 \%$ of the Icelanders. Almost a third of the Icelanders disagreed with the statement, indicating that they believed the government does care, as compared to one-fifth of the participants with a non-Icelandic background. Again, the answers of Filipinos come closest to the Icelandic answers. The majority of the Lithuanian (63\%) and Polish (59\%) participants were skeptical about the Icelandic government caring for them. These percentages are lower among Filipino $(35 \%)$ and Icelandic participants $(47 \%)$. Again, there are no significant gender differences observed among Icelandic citizens $\left(\chi^{2}:(2, \mathrm{n}=702)=0,447, \mathrm{p}=\right.$ n.s. $)$ or among citizens with a foreign background $\left(\chi^{2}:(2 \mathrm{n}=151)=2.419, \mathrm{p}=\mathrm{ns}\right)$.

Table 2. The government doesn't care what people like me think

\begin{tabular}{lcccc}
\hline & Icelandic background & Lithuanian background & Polish background & Filipino background \\
\hline Agree & $47 \%(334)$ & $63 \%(37)$ & $59 \%(24)$ & $35 \%(18)$ \\
Neutral & $21 \%(148)$ & $22 \%(13)$ & $22 \%(9)$ & $41 \%(21)$ \\
Disagree & $32 \%(222)$ & $15 \%(9)$ & $20 \%(8)$ & $24 \%(12)$ \\
Total & 100 & 100 & 100 & 100 \\
\hline
\end{tabular}

$\chi^{2}:((, \mathrm{n}=855)=21,049, \mathrm{p}=0.002$

If we now turn to the citizens' own situation and ask how knowledgeable they are about political issues, we discover that $63 \%$ of the Icelandic citizens felt that they have a good understanding of important political issues, in comparison to $38 \%$ of the participants with a non-Icelandic background. Table 3 presents a more detailed picture of the situation by displaying the data according to various participant backgrounds. Here it can be seen that the participants with a Lithuanian background were the least confident that they have a good understanding of important political issues, $41 \%$ of the sample disagreed with the statement, whereas the Icelandic citizens (10\%) and citizens with a Filipino background $(8 \%)$ were the least likely to disagree. Gender does not play a significant role in this context.

Table 3. I have a good understanding of important political issues

\begin{tabular}{lcccc}
\hline & Icelandic background & Lithuanian background & Polish background & Filipino background \\
\hline Agree & $63 \%(444)$ & $37 \%(20)$ & $33 \%(11)$ & $42 \%(22)$ \\
Neutral & $27 \%(186)$ & $22 \%(12)$ & $30 \%(10)$ & $50 \%(26)$ \\
Disagree & $10 \%(71)$ & $41 \%(22)$ & $36 \%(12)$ & $8 \%(4)$ \\
Total & $100 \%(701)$ & $100 \%(54)$ & $100 \%(33)$ & $100 \%(52)$ \\
\hline
\end{tabular}

$\chi^{2}:(6, \mathrm{~N}=840)=74.521, \mathrm{p}=0.000$ 
Our final variable measuring political efficacy revolves around how well citizens feel they are informed. Whereas the majority of the Icelandic citizens felt they are well informed themselves (62\%), the majority of citizens with a non-Icelandic background $(52 \%)$ felt that others are better informed than they are. This difference is significant $\left(\chi^{2}:(2, n=844)=206,377, p=0.000\right)$. However, we also observe a gender difference, with a larger proportion of Icelandic men (67\%) than women (58\%) believing that they themselves are better informed than others. A significant gender pattern is also present among citizens with a non-Icelandic background but in a different form; here, the men agree to a larger extent (64\%) than the women $(45 \%)$ that most people are better informed than they are $\left(\chi^{2}:(2, n=142)=6.230, p=0.044\right)$. When the different backgrounds are taken into account (Table 4) it can be seen that citizens with a Polish background felt the least informed, followed by the participants with a Lithuanian background and a Filipino background.

Table 4. Most people are better informed than I am

\begin{tabular}{lcccc}
\hline & Icelandic background & Lithuanian background & Polish background & Filipino background \\
\hline Agree & $7 \%(49)$ & $53 \%(29)$ & $63 \%(22)$ & $44 \%(23)$ \\
Neutral & $31 \%(218)$ & $29 \%(16)$ & $17 \%(6)$ & $39 \%(20)$ \\
Disagree & $62 \%(435)$ & $18 \%(10)$ & $20 \%(7)$ & $17 \%(9)$ \\
Total & $100 \%(702)$ & $100 \%(55)$ & $100 \%(35)$ & $100 \%(52)$ \\
\hline
\end{tabular}

$\chi^{2}:(6, \mathrm{~N}=844)=214.502, \mathrm{p}=0.000$

Overall, the findings regarding political efficacy reveal that, up to a certain extent, participants with a foreign background felt less connected and less cared for by the Icelandic government, and they sensed that they were less knowledgeable and less informed than participants with an Icelandic background. However, Filipino participants seemed to have slightly more moderate opinions than the other two foreign background groups.

\subsection{Being a good citizen}

Most participants found it important to act as a good citizen, for instance by voting in elections, not trying to evade taxes, keeping an eye on the actions of the government, being active in associations, understanding other opinions, choosing products for political or environmental reasons, and helping less privileged people in Iceland and in the rest of the world. The means for the different citizen groups fluctuate between 5.1 (Lithuanian background) and 5.8 (Filipino background), in which a higher score represents ascribing more value to the issue, with Icelandic citizens (5.3) and participants with a Polish background (5.4) being situated somewhere in between $(F(3,801)=6,835$, $\mathrm{p}=0.000)$. This means that participants with a Filipino background found the issue most important; they found it slightly more important than Icelandic citizens did, for instance. Icelandic women however did score on average somewhat higher (5.5) on this scale than 
Icelandic men (5.2) (T-test [592.93] =-4.631, $\mathrm{p}=0.000)$, a gender difference that was not observed among any of the other background groups.

\subsection{Subjective social status and top/bottom placement}

The subjective social status of minority groups, or people with a foreign background, is supposedly lower than that of natives. This also becomes apparent when looking at the top/bottom placement of the different background groups. Whereas all three nonIcelandic background groups scored an average of 5.5, the group of Icelandic citizens ranked themselves significantly higher, with a mean of $6.1(F[3,683]=3.653, p=0.012)$. Gender does not play a significant role in the top/bottom placement here.

Although background plays a role in top/bottom placement, we were curious as to whether other variables affect the top/bottom placement of citizens as well. A regression analysis (Table 5) reveals that the variables income, years of education, age, and paid employment are also predictors of top/bottom placement. That is, the more income people generate, the more years of schooling they have, and the older they are, the higher they place themselves on the top/bottom scale. On the contrary, lacking paid employment and being of foreign origin leads to a lower placement on this scale, but the variable of sex is insignificant in this model. Together, these variables explain $13.9 \%$ of the variation in the top/bottom placement scale.

Table 5. Regression analysis on the outcome variable top-bottom placement

\begin{tabular}{lcccc}
\hline & \multicolumn{2}{c}{ Model 1 } & \multicolumn{2}{c}{ Model 2 } \\
& $\mathrm{b}$ & $\mathrm{SE}$ & $\mathrm{b}$ & $\mathrm{SE}$ \\
\hline Constant & 6.1 & & 3.64 & 0.58 \\
Immigrant background & $-0.62^{* *}$ & 0.186 & -0.18 & 0.23 \\
Income & & & $0.001^{* *}$ & 0.00 \\
Years of schooling & & $0.108^{* *}$ & 0.022 \\
Not in paid employment & & $-1.14^{* *}$ & 0.28 \\
Age & & 0.02 & 0.01 \\
Women & & 0.016 & 0.25 & 0.16 \\
\hline $\mathrm{R}^{2} /$ Adjusted $\mathrm{R}^{2}$ & & Adjusted $\mathrm{R}^{2}$ & 0.152 \\
\hline * $<<0.05 * * \mathrm{p}<0.01)$ Model 1: $\mathrm{F}(1,685)=10.99, \mathrm{p}=0.001$ & Model 2: $\mathrm{F}(6,464)=15.08, \mathrm{p}=0.000$ &
\end{tabular}

\section{Discussion}

In this paper, we examined how people from Poland, Lithuania, and the Philippines (the largest European and Asian immigrant groups in Iceland) experience their participation and position within Icelandic society. We were interested in their political integration, their vision of being a good citizen, and whether they experienced their situation differently than people with an Icelandic background. Using Marshall's account of social citizenship (1950) as a point of departure, we used theoretical concepts in sociology and political science in our discussion, covering social and political integration (Joppke 
2017), political efficacy and alienation (Anduiza \& Josep 2011; Konttinen \& Kouvo 2009; Almond \& Verba 1963), the notion of being a good citizen, and subjective social status (Adler \& Stewart 2007; Gidron \& Hall 2017). We also analyzed whether there were differences in these traits among countries within and outside the EEA area.

Overall, we found that participants with a foreign background felt less connected and less cared for by the Icelandic government, and they sensed that they were less knowledgeable and less informed than participants with an Icelandic background. Although it has been argued that immigrants may only feel the need to integrate to the extent of being able to communicate and function in Icelandic society (Innes \& Skaptadóttir 2017), the findings of this study do reveal some signs of integration processes that go further than just being able to communicate and function. Our study shows that there is a small group of citizens with a non-Icelandic background that feel they can influence the Icelandic government and that the government does care about them. This group is also confident that they understand the political issues in the country, and they rate themselves as being well informed. Unfortunately, this group only represents the minority of the immigrants in our study. However, our study is in line with Skaptadóttir's studies (2010, 2015a) demonstrating that despite the difficulties associated with immigrants outside the EEA working legally in Iceland, participants from the Philippines, at least the most privileged, seem to have adapted relatively well compared to participants from Poland and Lithuania.

Based on available studies about the situation of immigrants in Iceland, it is not surprising that differences between Icelandic and non-Icelandic participants were apparent in our measures. Participants with an Icelandic background were overall more confident about these issues than participants with a foreign background, although it should be noted that there was significant variety among the answers of Icelanders themselves as well. This may indicate that Icelanders themselves may not feel as integrated into their own society as one would expect, or alternatively that these statements measure not only integration but another latent concept as well. Thus, it is important to understand why Filipinos, who do not belong to the EEA and consequently have more trouble moving to Iceland, were more likely than participants from East Europe to give replies similar to those of the Icelandic participants. Does this mean that social and political integration have been easier for Filipinos than for participants from Poland and Lithuania? If so, how do we explain this?

No significant differences were found between the views of immigrants and Icelanders in terms of what it means to be a good citizen. Both groups felt that this was important, although women slightly more than men. Although the immigrants in our study did value the notion of being a good citizen, we nevertheless found that immigrants differed in their feelings on political efficacy, and only a minority felt that the government cares about them. Although immigrants' views of being left behind by the government are of great concern, we take the importance of being a good citizen as a sign of willingness among current immigrants to be part of and to integrate into Icelandic society.

Whether these findings were influenced by the fact that most of the participants were 
active in the labor market is something we can only speculate about. Previous studies have highlighted the segregation of the Icelandic labor market (Loftsdóttir, Sigurðardóttir \& Kristinsson 2016; Vinnumálastofnun 2018; Skaptadóttir 2015b), which provides some foreigners few opportunities to make contact with Icelanders, despite their employment status. However, when immigrants do work in an environment with Icelandic people, their employment may help them integrate into Icelandic society more quickly.

Our analysis reveals that the subjective social status of the participants with a nonIcelandic background was lower than that of Icelanders; immigrants ranked themselves lower on the top/bottom placement than Icelanders. However, other variables — such as income, education, paid employment, and age-also turned out to play a role in this context. Although the regression put the three groups of non-Icelanders together, the results probably explain the differences between the views of participants from East Europe and those of Filipino participants in terms of social and political integration. As pointed out before, a large percentage of Filipinos in Iceland have, different from immigrants from East Europe, university degrees and are educated as health care personnel (Skaptadóttir 2015; Vinnumálastofnun 2017). In addition, the highest proportion of work permits based on "special knowledge" was given to people from Asia during the years 2012-2017 (Vinnumálastofnun 2018).

Our results indicate that there is an opportunity to improve the subjective social status of immigrants and therefore their overall situation within Icelandic society. Gaining additional education may lead to a better job and higher income, which in turn could improve both the integration of immigrants into Icelandic society and benefit their personal situations. That said, we must be aware that the variables in this regression analysis only explain the subjective social status of people in Icelandic society up to a limited extent.

The strength of this study is that it uses the ISSP dataset to address and compare questions about the social and political integration of the largest European and Asian immigrant groups in Iceland. However, because the sample of participants with foreign backgrounds was small and the response rate in the additional data collection was low, the data may not be representative of the total population for each country. This is a weakness that is well known among quantitative studies on immigrant populations. Nevertheless, our results are important indicators in the evaluation of the status of this group of foreigners in Icelandic society. It would be of great interest to develop this study by doing a similar analysis for these groups of foreigners in their own countries and compare these results with those we obtained in Iceland. In this way, we could better understand the differences in the social and political positions of Polish, Lithuanian, and Filipino immigrants in Iceland on the one hand and in their own countries on the other.

\section{Conclusion}

Following the large influx of immigrants in the past decade, a complex situation appears to be emerging in Iceland in relation to economic and political integration. The issues we have explored reveal a compound situation among both non-Icelandic participants 
(from Poland, Lithuania, and the Philippines) and Icelandic participants. Although there seems to be a certain group of non-Icelandic participants who are relatively well integrated, this picture of integration by no means applies to all immigrants to Iceland. Respondents from the Philippines were more likely to feel integrated than those from Poland and Lithuania. This is interesting because due to the EEA and Schengen agreements, it is more difficult for people from Asian countries to move to Iceland than for people from East Europe.

Although Iceland has been attracting immigrants in search of employment, social integration in Iceland has become more complicated because of a segregated labor market. This makes it more challenging for immigrants to socially integrate, even if they are employed. Political integration is a much less researched area, and there is very little information on the political integration of immigrants in Iceland (e.g., their voting turnout). Our results indicate that the political integration of immigrants to Iceland has been partially successful, but there are immigrants who do not feel heard and do not feel that they can influence political matters. They also feel that they lack knowledge and place themselves lower on the social scale than Icelanders. In order to prevent immigrants from feeling alienated from society, there is a need for further integration opportunities, for instance by means of additional education and job opportunities. Only then can the legitimacy of the current system be secured.

\section{References}

Adler, N., and Stewart, J. (2007). The MacArthur Scale of Subjective Social Status. Retrieved May 14, 2018 from http://www.macses.ucsf.edu/research/psychosocial/subjective.php

Almond, G., and Verba, S. (1963). The Civic Culture: Political Attitudes and Democracy in Five Nations. Princeton: Princeton University Press.

Anduiza, E., and San Martin, J. (2011). "Political Efficacy and Confidence Among Migrants", in L. Morales and M. Giugni (eds.), Social capital, political participation and migration in Europe: Making multicultural democracy work? Palgrave Macmillan.

Barillé, S., and Meckl, M. (2017). "Migrants' Experience of Happiness and Well-being in Northern Iceland", Nordicum-Mediterraneum. Icelandic E-Journal of Nordic and Mediterranean Studies 12(1).

Bevelander, P., and Pendakur, R. (2010). "Voting and Social Inclusion in Sweden", International Migration 49(4), 67-92.

Blom, R. (2009). "Divergent Citizenship", in A. Konttinen (ed.), Civic mind and good citizenship: Comparative perspectives. Tampere: Tampere University Press.

Borevi, K. (2010). "Dimensions of Citizenship. European Integration Policies from a Scandinavian Perspective" in B. Bengtsson, P. Strömblad, and A.H. Bay (eds.), Diversity, inclusion and citizenship in Scandinavia. Newcastle: Cambridge Scholars Publishing.

Borevi, K., Jensen, K.K., and Mouritsen, P. (2017). "The Civic Turn of Immigrant Integration Policies in the Scandinavian Welfare States", Comparative Migration Studies 5(9).

Chaudary, A.R. (2017). "Voting Here and There: Political Integration and Transnational Political Engagement Among Immigrants in Europe", Global Networks. DOI: https://doi.org/10.1111/glob.12171.

Christiansen, D., and Kristjánsdóttir, E. (2016). “„Veggurinn er alltaf til staðar“: Upplifun háskólamenntaðra innflytjenda af samskiptum og samningsstöðu gagnvart vinnuveitendum”, Íslenska pjódfélagið 7(1), 5-22.

Dale, T., and Haraldsen, G. (2000). “Turning Nonresponse into Response in Surveys Among Immigrants". Unpublished paper presented at the 2000 Workshop for Household Survey Nonresponse. Budapest. 
Deding, M., Fridberg, T., and Jakobsen, V. (2008). "Non-response in a Survey Among Immigrants in Denmark", Survey Research Methods 2(3), 107-121.

Einarsdóttir, K.Á. (2011). "Young Unemployed Migrants in Iceland: Opportunities on the Labour Market and Situations after the Economic Collapse with Regard to Work, Social and Financial Aspects", unpublished MA thesis, Faculty of Social and Human Sciences. University of Iceland: Reykjavík.

Einarsdóttir, D., and Gústafsdóttir, G. (2008). "Innflytjendastefna ríkisstjórnarinnar í ljósi pegnréttar og kyngervis”, in G.P. Jóhannesson (ed.), Rannsóknir i félagsvísindum IX, 345-356. Reykjavik: Social Science Research Institute.

Félagsmálaráðuneytið (2007). "Stefna ríkisstjórnarinnar um aðlögun innflytjenda", January 2007. Retrieved May 14, 2018 from https://www.stjornarradid.is/media/velferdarraduneyti-media/media/ acrobat-skjol/Stefna_um_adlogun_innflytjenda.pdf

Feskens, R., Hox, J., Lensvelt-Mulders, G., and Schmeets, H. (2007). "Nonresponse Among Ethnic Minorities: A Multivariate Analysis", Journal of Offical Statistics 23, 387-408.

Feskens, R., Hox, J., Lensvelt-Mulders, G., and Schmeets, H. (2006). "Collecting Data Among Ethnic Minorities in an International Perspective", Field Methods 18(3), 284-304.

Friberg, J., Arnholtz, J., Eldring, L., Hansen, W. N., and Thorarins, F. (2014). "Nordic Labour Market Institutions and new Migrant Workers: Polish Migrants in Oslo, Copenhagen and Reykjavik", European Journal of Industrial Relations 20(1), 37-53.

Garðarsdóttir, Ö., and Bjarnason, P. (2010). “Áhrif efnahagsprenginga á fólksflutninga til og frá landinu”, in G.P. Jóhannesson and H. Björnsdóttir (eds.), Rannsóknir i Félagsvísindum XI: Félags- og mannvísindadeild (1-11). Reykjavik: Social Science Research Institute.

Giddens, A. (2000). Runaway World. How Globalisation is Reshaping our Lives. New York: Routledge.

Gidron, N., and Hall, P.A. (2017). "Populism as a Problem of Social Integration”, Working Paper. Paper prepared for presentation at the Annual Meeting of the American Political Science Association, San Francisco, September 1, 2017. Retrieved September 25, 2017 from https://scholar.harvard.edu/ files/hall/files/gidronhallapsa2017.pdf

Huws, U. (2012). "Bridges and Barriers: Globalisation and the Mobility of Work and Workers", Work Organisation, Labour and Globalisation 6(2), 1-7.

Innes, P., and Unnur Dís Skaptadottir. (2017). "Immigrant Experiences of Learning Icelandic and Connecting with the Speaking Community", Nordic Journal of Migration Research 7(1), 20-27.

Innes, P., and Unnur Dís Skaptadottir. (2016). "Icelandic for Adult Foreigners: Effects of Imposing an Icelandic Language Test. Current Issues in Language Planning (published online) 18(1), 68-86.

Joppke, C. (2007). "Beyond National Models: Civic Integration Policies for Immigrants in Western Europe", West European Politics 30(1), 1-22.

Joppke, C. (2017). "Civic Integration in Western Europe: Three Debates“, West European Politics 40(6), 1153-1176.

Júlíusdóttir, M., Skaptadóttir, U.D., and Karlsdóttir, A. (2013). "Gendered Migration in Turbulent Times in Iceland”, Norwegian Journal of Geography 67(5), 266-275.

Konttinen, A. (2009). "The Idea of Citizenship in a Globalized World”, in A. Konttinen (ed.), Civic mind and Good Citizenship: Comparative Perspectives. Tampere: Tampere University Press.

Kristjánsdóttir, Í.B. (2010). "Lög um útlendinga á Íslandi: Mannfræðirýni á lagaumhverfi innflytjenda á Íslandi frá 1920 til 2009”, unpublished MA-thesis. Faculty of Social and Human Sciences. University of Iceland: Reykjavík.

Larja, L., and Kotilainen, A. (2014). "Immigrant Respondents and Quality in Population Surveys: Sampling, Non-response \& Questionnaire design", European Conference on Quality in Official Statistics. Statistics Finland: Q2014, Vienna (2.6.2014).

Loftsdóttir, K. (2015a). "The Exotic North: Gender, Nation Branding and Nationalism in Iceland", Nora - Nordic Journal of Feminist and Gender Research 23(4), 246-260.

Loftsdóttir, K. (2015b). “Grín, íslam og fordómar í fjölmenningarlegu samfélagi”, Ritid 15(1), 201-217. 
Loftsdóttir, K., Sigurðardóttir, M.S., and Kristinsson, K. (2016). "Hún gæti alveg verið Múslimi og allt pað: Ráðning fólks af erlendum uppruna til Íslenskra fyrirtækja”, Icelandic review of Politics and Administration 12(2), 393-416.

Marshall, T.H. (1950). Citizenship and Social Class and Other Essays. London: Cambridge University Press.

Morales, L. (2011). "Conceptualizing and Measuring Migrant's Political Inclusion”, in Morales and Marco (eds.), Social capital, political participation and migration in Europe: Making multicultural democracy work?. Palgrave Macmillan.

Morales, L., and Giugni, M. (2011). "Political opportunities, social capital and the political inclusion of immigrants in European cities”, in Morales and M. Giugni (eds.), Social Capital, Political Participation and Migration in Europe: Making Multicultural Democracy Work?. Palgrave Macmillan.

Oddsson, G.Æ. (2010). "Class Awareness in Iceland”, International Journal of Sociology and Social Policy $30(5 / 6), 292-312$.

Ólafsson, K., and Meckl, M. (2013). "Foreigners at the end of the Fjord. Inhabitants of Foreign Origin in Akureyri”, in H. Ólafs and T.M. Heijstra (eds.), Djódarspegillinn, rannsóknir í félagsvísindum XIV: Félags- og mannvísindadeild (1-11). Reykjavik: Social Science Research Institute.

PEW Research Center (2012). Assessing the Representativeness of Public Opinion Surveys. Washington: Pew Research Center. Retrieved from: http://assets.pewresearch.org/wp-content/uploads/ sites / 5/legacy-pdf/Assessing $\% 20$ the $\% 20$ Representativeness $\% 20$ of $\% 20$ Public $\% 20$ Opinion $\% 20$ Surveys.pdf

Sigurðsson, K. (2016). “Staða og horfurá vinnumarkaði á árunum 2016 - 2018”. Reykjavík: Vinnumálastofnun. Retrieved December 15, 2017 from https://www.vinnumalastofnun.is/media/1621/stadaog-horfur-a-vinnumarkadi.pdf

Simonsen, K.B. (2017). "Does Citizenship Always Further Immigrants' Feeling of Belonging to the Host Nation? A Study of Policies and Public Attitudes in 14 Western Democracies", Comparative Migration Studies 5(9).

Skaptadóttir, U.D. (2010a). “Alpjóðlegir fólksflutningar á tímum efnahagslegs samdráttar”, í G.P. Jóhannesson and H. Björnsdóttir (eds.) XI, 310-322. Reykjavik: Social Science Research Institute.

Skaptadóttir, U.D. (2010b). "Integration and Transnational Practices of Filipinos in Iceland", Emigrinter 5, 36-45. Retrieved May 14, 2018 from http://www.mshs.univ-poitiers.fr/migrinter/e-migrinter/201005/emigrinter2010_05_tout.pdf\#page=38

Skaptadóttir, U.D. (2012). "Pátttaka innflytjenda", in G.H. Kristinsson, M.S. Björnsdóttir and S.A. Jóhannsdóttir (eds.), Leiðsögn um lýdraði i sveitarfélögum. Reykjavík: Samband íslenskra sveitarfélaga og Stofnun stjórnsýslufræða og stjórnmála við Háskóla Íslands

Skaptadóttir, U.D. (2015a). "Women and Men on the Move: From the Philippines to Iceland", in S.Th. Faber and H.P. Nielsen (eds.), Remapping Gender, Place and Mobility: Global Confluences and Local Particularities in Nordic Peripheries (143-156). Surrey: Ashgate Publishing Limited.

Skaptadóttir, U.D. (2015b). "What Happened to the Migrant Workers?", in E. Paul Durrenberger and G. Pálsson (eds.), Gambling Debt: Iceland's Rise and Fall in the Global Economy (175-186). Boulder: University Press of Colarado.

Statistics Iceland. (2017). Iceland in figures 2017. Reykjavík: Statistics Iceland. Retrieved May 14, 2018 from http://www.statice.is/media/50481/icelandinfigures2017.pdf

Vinnumálastofnun (2017). "Vinnumarkaðurinn á Íslandi. Yfirlit, horfur og pjónusta Vinnumálastofnunar”, August 2017. Retrieved 5 May, 2018 from https://www.vinnumalastofnun.is/media/1876/ agust-2017-skyrsla.pdf

Vinnumálastofnun (2018). "Erlendir ríkisborgarar á íslenskum vinnumarkaði á árunum 2012 - 2017 ”. Retrieved 10 May 2018 from https://www.vinnumalastofnun.is/media/2003/erlendir-rikisborgarar-2012-2017-endanlegt.pdf

Wojtnynska, A. (2011). "From Shortage of Labour to Shortage of Jobs: Polish Unemployed Migrants in Iceland”, in Á.G. Ásgeirsdóttir, H. Björnsdóttir and H. Ólafs (eds.), Djóðarspegillinn. Rannsóknir ifélagsvísindum XII: Félags- og mannvísindadeild (46-56). Reykjavik: Social Science Research Institute. 
Young, I.M. (1989). "Polity and Group Difference: A Critique of the Ideal of Universal Citizenship", Ethics 99, 250-274.

Önnudóttir, E.H. (2009). "Viðhorf Íslendinga til innflytjenda á Íslandi”, Bifröst Journal of Social Science 3, 67-95. 